\title{
Extra-cellular Isoamylase Production by Rhizopus oryzae in Solid-State Fermentation of Agro Wastes
}

\author{
Barnita Ghosh and Rina Rani Ray* \\ Microbiology Laboratory; Department of Zoology; Molecular Biology and Genetics; Presidency University; \\ Kolkata, 700 073, India
}

\begin{abstract}
Extra-cellular isoamylase was produced by Rhizopus oryzae PR7 in solid-state fermentations of various agro wastes, among which millet, oat, tapioca, and arum (Colocasia esculenta) showed promising results. The highest amount of enzyme production was obtained after $72 \mathrm{~h}$ of growth at $28^{\circ} \mathrm{C}$. The optimum $\mathrm{pH}$ for enzyme production was - 8.0. Among the various additives tested, enzyme production increased with ions such as $\mathrm{Ca}^{2+}, \mathrm{Mg}^{2+}$ and also with cysteine, GSH, and DTT. The enzyme synthesis was reduced in the presence of thiol inhibitors like $\mathrm{Cu}^{2+}$ and pCMB. The surfactants like Tween-40, Tween-80 and Triton X-100 helped in enhancing the enzyme activity. The production could be further increased by using the combinations of substrates. The ability to produce high amount of isoamylase within a relatively very short period and the capability of degrading wastes could make the strain suitable for commercial production of the enzyme.
\end{abstract}

Key words: Isoamylase, Rhizopus oryzae, SSF, waste utilization

\section{INTRODUCTION}

Enzymes are among the most important products obtained for human needs through microbial sources. A large number of industrial processes in the areas of industrial, environmental and food biotechnology utilize enzymes at some stage or the other. However, high cost of enzyme production in conventional submerged fermentation $(\mathrm{SmF})$ has hindered their industrial applications, which necessitates the adoption of some alternative method. Solid-state fermentation (SSF) using agricultural wastes as sole carbon source can be an attractive alternative method (Pandey et al., 1992) as it offers numerous advantages over submerged fermentation system, including high volumetric productivity, relatively higher concentration of the products, less effluent generation, requirement for simple fermentation equipments and cost effectiveness. Actually, SSF process takes place in the absence and near absence of free water, thus being close to the natural environment to which microorganisms are adapted (Pandey, 1992). In SSF, since the growth is restricted to the surface of the solid matrix (Tengerdy, 1998) and the culture is not exposed to hydrodynamic forces, relatively higher amount of enzymes are expected to be produced.

Though historically established centuries ago, this technique of fermentation could gain a fresh attention from researchers since the past one decade, mainly because of a number of major advantages which SSF offers over liquid (submerged) fermentation $(\mathrm{SmF})$, particularly in

*Author for correspondence: rina_ray64@yahoo.co.in 
the areas of solid waste management, biomass energy conservation and its application to produce secondary metabolites (Pandey, 1992).In recent years research interest in batch solid-state fermentation (SSF) has addressed the production of many innovative and high value products, e.g. single-cell protein (SCP), protein enriched feed, ethanol, enzymes, mycotoxins, from starchy materials and a variety of wastes utilized by fungi (Pandey et al., 1999). The use of filamentous fungi for the production of commercially important metabolites has increased rapidly over the past half century and the preference of production of fungal enzymes in submerged fermentation $(\mathrm{SmF})$ has been rapidly switched over to SSF.

Starch is a major storage product of nature and a large-scale starch processing industry has emerged in the last century, where gradually came a shift from the trend of acid hydrolysis of starch to the use of starch-converting enzymes in the production of maltodextrin, modified starches, or glucose syrups. Amylases are among the most important enzymes used in modern biotechnology, particularly in the processes involving starch hydrolysis (Arlem Nascimento de et al., 2010) and currently, comprise about $30 \%$ of the world's enzyme production. Besides the use in starch hydrolysis, starch-converting enzymes are also used in a number of other industrial applications, such as laundry and porcelain detergents or as anti-staling agents in baking. These starchconverting enzymes belong to a single family: the amylase family, of which isoamylase (glycogen-6glucanohydrolase, E.C.3.2.1.68) hydrolyses 1, 6- $\alpha$ D-glycosidic linkages of glycogen, amylopectin and $\alpha$ and $\beta$ limit dextrins, producing linear malto oligosaccharides (Fang et al., 1994). Isoamylase was used primarily in the production of food ingredients from starch like glucose, maltose, trehalose and cyclodextrins (Olemposka-Beer, 2007). Although SSF of various microorganisms were used for the production of $\alpha$ - amylase (Kar et al., 2010), $\alpha$-galactosidase (Kapnoor et al., 2010), glucoamylase (Zambare, 2010), endoglucanase (Karmakar and Ray, 2010), no report is available on production of microbial isoamylase from its solid-state fermentation of agro residues. The objective of the present work was to study the production of isoamylase by a strain of Rhizopus oryzae from the SSF of various starchy agro wastes and evaluation of various parameters for the optimization of such production.

\section{MATERIALS AND METHODS}

\section{Microorganism}

Rhizopus oryzae PR7 MTCC 9642 (Ghosh and Ray, 2010)-, was used in this study.

\section{Chemicals}

All the chemicals used were of analytical grade. All the substrates used were collected from expired and dampened kitchen and grocery items, pulverized and were supplemented in the culture media in place of pure starch.

\section{Preparation of Inoculum}

The fungus was grown in $1 \%$ PDA plates at 28$30^{\circ} \mathrm{C}$ for $48 \mathrm{~h}$. The inocula were prepared by making hyphal discs $(0.5 \mathrm{~cm}$ diameter $)$. Each disc was used to inoculate $10 \mathrm{ml}$ of medium (Ray and Chakraverty, 1998).

\section{Cultivation of the Strain}

The strain was cultivated in LSF (Liquid State Fermentation) in $100 \mathrm{~mL}$ Erlenmeyer flasks each containing $20 \mathrm{~mL}$ Basal Medium (BM) composed of $\left(\mathrm{g} \mathrm{L}^{-1}\right)$ : peptone 0.9; $\left(\mathrm{NH}_{4}\right)_{2} \mathrm{HPO}_{4} 0.4 ; \mathrm{KCl} \mathrm{0.1}$; $\mathrm{MgSO}_{4} .7 \mathrm{H}_{2} \mathrm{O} 0.1$ and starch 0.25. (pH: 8.0).

\section{Cultivation in Solid-State Fermentation Medium}

$R$. oryzae was cultured in $50 \mathrm{~mL}$ Erlenmeyer flasks containing totally dried substrates (50mg) and salts (based on $10 \mathrm{~mL}$ medium) moistened with distilled water/buffer $(0.5 \mathrm{ml})$ at $28^{\circ} \mathrm{C}$.Each flask was inoculated by a disc of $0.5 \mathrm{~cm}$ diameter from PDA plates .The flasks were picked up at different time intervals. Sterile water was added to each flask to make up its final volume equivalent to that of $10 \mathrm{~mL}$ LSF medium, followed by a thorough cyclomixing.

\section{Enzyme Assay}

In SSF, after the addition of sterile water and thorough mixing, the broth was filtered through filter paper (Whatman No. 1); the filtrate was centrifuged at $10,000 \mathrm{x}$ gfor $5 \mathrm{~min}$ and the supernatant was used as the crude enzyme (Chimata et al., 2010). To measure the activity of isoamylase, the assay mixture $(1 \mathrm{~mL})$ containing an equal volume of enzyme and $1 \%(\mathrm{w} / \mathrm{v})$ oyster glycogen dissolved in $0.1(\mathrm{M})$ phosphate buffer (pH5.0) was incubated at $55^{\circ} \mathrm{C}$ for $5 \mathrm{~min}$. The reducing sugar released was measured by the 
dinitrosalicylic acid method (Miller, 1959), taking glucose as standard. Blanks were prepared with inactivated enzymes. One unit of isoamylase was defined as that amount of enzyme that liberated 1 milli mole of glucose per milliliter per minute of reaction.

\section{Optimization of Parameters}

The inducing effect of various agro wastes were tested for isoamylase production by cultivating the strain in SSF of different starchy agro residues. The preferred concentration of the substrate used in SSF was estimated by adding various concentrations $(0.125-1 \% \mathrm{w} / \mathrm{w})$ of substrate in culture media as sole carbon source, i.e., for each type of starch source namely oat, millet, arum and tapioca, five sets of flasks with variable concentrations $(0.125-1 \% \quad \mathrm{w} / \mathrm{w})$ were prepared. The inoculums size was optimized by cultivating the strain with varied number of hyphal discs prepared from PDA plate containing $R$. oryzae. Agro waste supplemented cultures were incubated at $18^{\circ}-48^{\circ} \mathrm{C}$ to check the preferred temperature for isoamylase production. The optimum $\mathrm{pH}$ was determined by adjusting the $\mathrm{pH}$ of the agro waste supplemented fermentation media at a range of 4.0-9.0 by moistening the media with the buffer presenting the respective $\mathrm{pH}$. For verification, the initial $\mathrm{pH}$ was checked by adding sterile water in the flask, followed by the measurement by a $\mathrm{pH}$ meter. The initial moisture content of the media was adjusted by moistening the substrate $(50 \mathrm{mg})$ with variable amount of buffer $(0.25 \mathrm{ml}-1.5 \mathrm{ml})$. As nitrogen sources play an important role in enhancing the enzyme production, the effects of nitrogen sources were tested by adding peptone, tryptone, yeast extract, urea and potassium nitrate $0.09 \%(\mathrm{w} / \mathrm{v})$ separately in each culture flask (Chimata et al., 2010). Fermentation time was optimized by cultivating the strain in optimized media for various time periods (24-120h) and assaying the enzyme produced from them. In order to check the effect of salts, $10 \mathrm{mM}$ of salts containing $\mathrm{Na}^{+}, \mathrm{K}^{+}, \mathrm{Ca}^{2+}, \mathrm{Cu}^{2+}, \mathrm{Mg}^{2+}$ and $\mathrm{Mn}^{2+}$ were added in the fermentation media. To study the effect of various additives on the four substrates used for isoamylase production, the medium was supplemented with $1 \mathrm{mM}$ of additives which included thiol compounds and surfactants. Two substrates were supplemented in one flask at a time to study their combined effect on enzyme synthesis. Each experiment was carried out in triplicate and their values were averaged.

\section{RESULTS AND DISCUSSION}

\section{Effect of Agro Waste as Inducer of Isoamylase Synthesis}

$R$. oryzae PR7 degraded various starchy agro wastes in solid-state fermentation conditions (Fig 1), of which millet, oat, arum and tapioca showed very promising results. Therefore, further experiments were carried out with millet, oat, arum and tapioca only. Although, starch and dextrin were used for the growth and isoamylase production (Spancer Martins, 1982; Takahashi et al., 1996, Ueda and Nanri, 1967, Olempska-Beer, 2007) by various organisms, no report was available on use of agro wastes for the production of isoamylase.

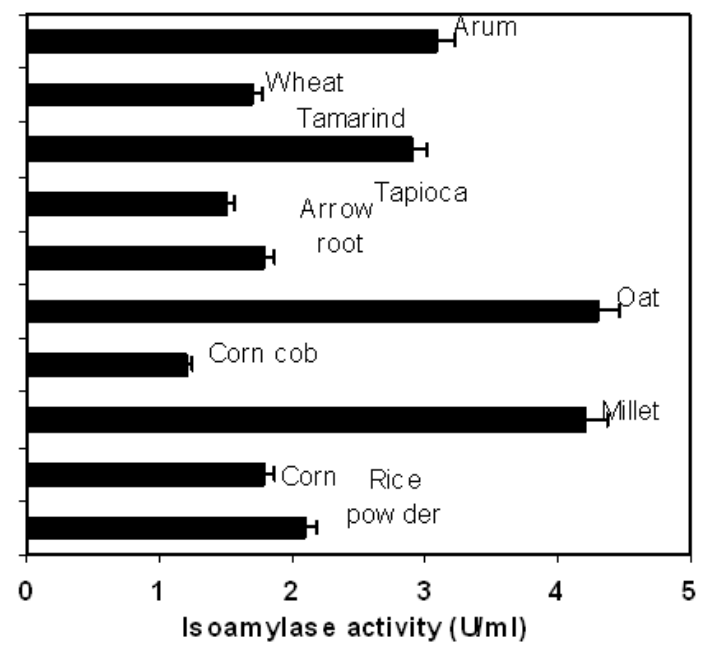

Figure 1 - Inducing effect of various starchy wastes on isoamylase production from the SSF of R.oryzae. 


\section{Effect of Substrate Concentration}

The concentration of all the four agro waste substrates that could best induce the growth and isoamylase production varied with the nature of the substrates used (Fig. 2).The optimum concentration for enzyme production of arum was $1 \%(\mathrm{w} / \mathrm{v})$, millet and oat at $0.25 \%(\mathrm{w} / \mathrm{v})$ and tapioca at $0.125 \%(\mathrm{w} / \mathrm{v})$. Higher concentration of arum could restore the amount of enzyme production, but increase in the concentration of millet, oat and tapioca in the fermentation media reduced the enzyme production probably due to the adverse effect of higher load of nutrient supplements present in these substrates (Omojasola et al., 2008), or as a result of hindrance of mass transfer of oxygen by higher amount of solid substrate.

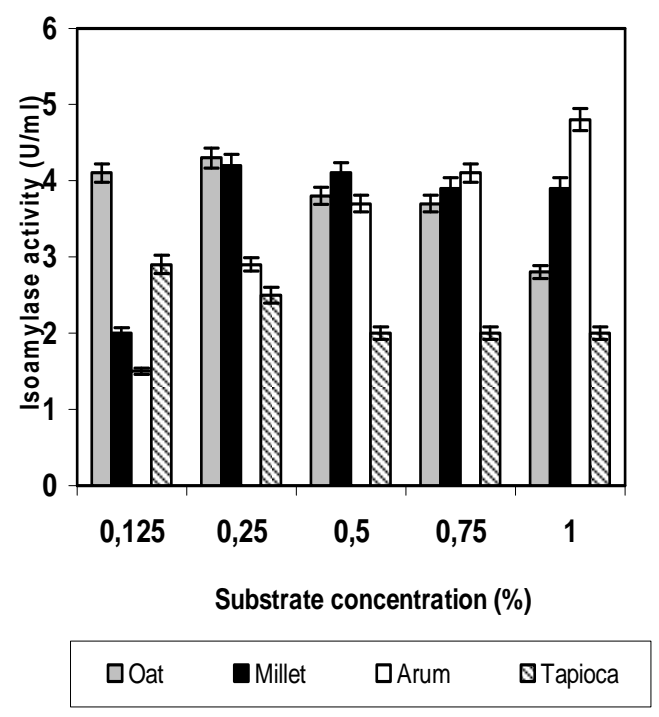

Figure 2 - Effect of substrate concentration on the production of isoamylase by R.oryzae.

\section{Effect of Inoculum size}

Inoculum size also affected the isoamylase production, as highest enzyme production was achieved (Fig. 3) when the culture media supplemented with all the four types of agro wastes individually were inoculated with two discs of $0.5 \mathrm{~cm}$ diameter. Increase in initial size of inoculum decreased the enzyme production, which might be due to the presence of higher load of fungal mass in the medium that in turn reduced the extent of enzyme production (Acharya et al., 2008).

\section{Effect of Temperature}

The production of extra-cellular isoamylase by $R$. oryzae PR7 was maximum at $28^{\circ} \mathrm{C}$ (Fig 4). At this temperature; it took up the filamentous form. But with the increase in temperature, under the influence of thermal dimorphism (Morrow and Fraser, 2009) it was converted to pellet form with drastic reduction in isoamylase synthesis. Although a lower temperature of $25^{\circ} \mathrm{C}$ was preferred by Lipomyces kononenkoae (Spancer Martins, 1982), the cultivation temperature for almost all of the reported isoamylase producer ranged between $28^{\circ}-30^{\circ} \mathrm{C}$ (Ueda and Nanri, 1967; Ara et al., 1993; Fang et al., 1994; Yamada et al., 1994; Takahashi et al., 1996; Olempska Beer, 2007).

\section{Effect of pH}

Optimization of $\mathrm{pH}$ on enzyme production indicated that best $\mathrm{pH}$-was 8.0 for all types of starchy wastes used (Fig. 5), which was higher than that from the mould Hendersonula toruloidea, cultivated at $\mathrm{pH} 5.5$ (Odibo et al., 1992), Xanthomonas maltophila showing a broad range of pH preference 6-8 (Yamada et al., 1994), but lower than Bacillus sp (Ara et al., 1993). 


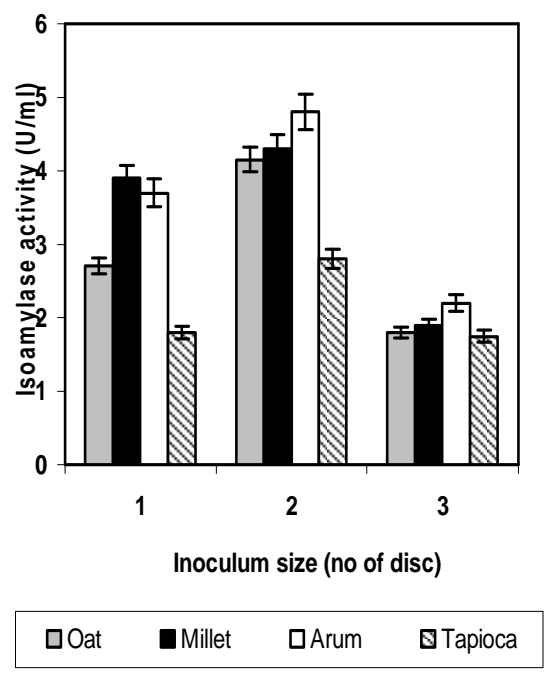

Figure 3 - Effect of inoculum size on the production of isoamylase by R.oryzae.

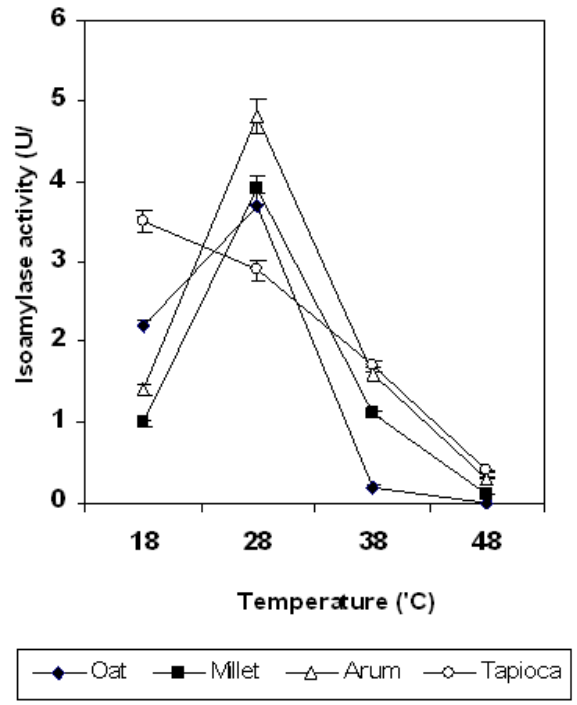

Figure 4 - Effect of temperature on the production of isoamylase by R.oryzae.

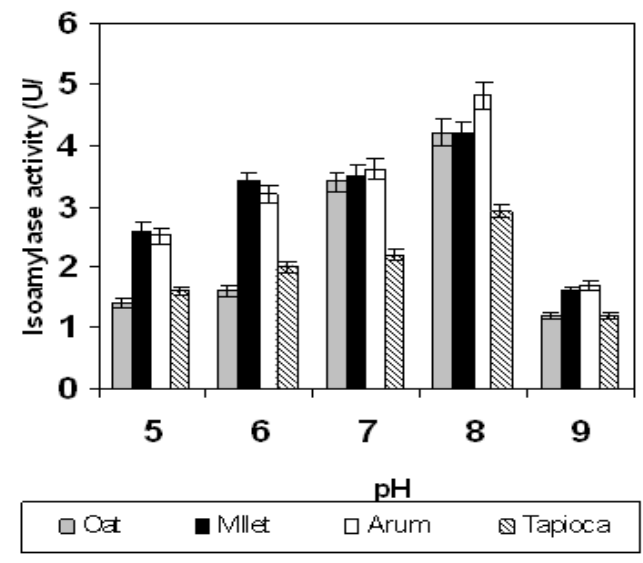

Figure 5 - Effect of $\mathrm{pH}$ on the production of isoamylase by R.oryzae. 


\section{Effect of moisture content}

It was found that best production occurred if the SSF media was moistened with $10 \%$ water (Fig 6), increase of which drastically reduced the enzyme yield.

\section{Effect of Nitrogen Sources}

Among the nitrogen sources tested, the results varied according to the agro wastes supplemented (Fig. 7). Peptone proved to be the best nitrogen source for enzyme production in case of oat and millet. Tryptone gave the best result in case of arum and tapioca. Yeast extract enhanced the enzyme activity in case of tapioca, an observation similar to that of Gomes et al., (2003). Enzyme production was remarkably increased in the presence of urea, for substrates like arum and tapioca, which was in accordance to a report by Aspergillus niger (Acharya et al., 2008).

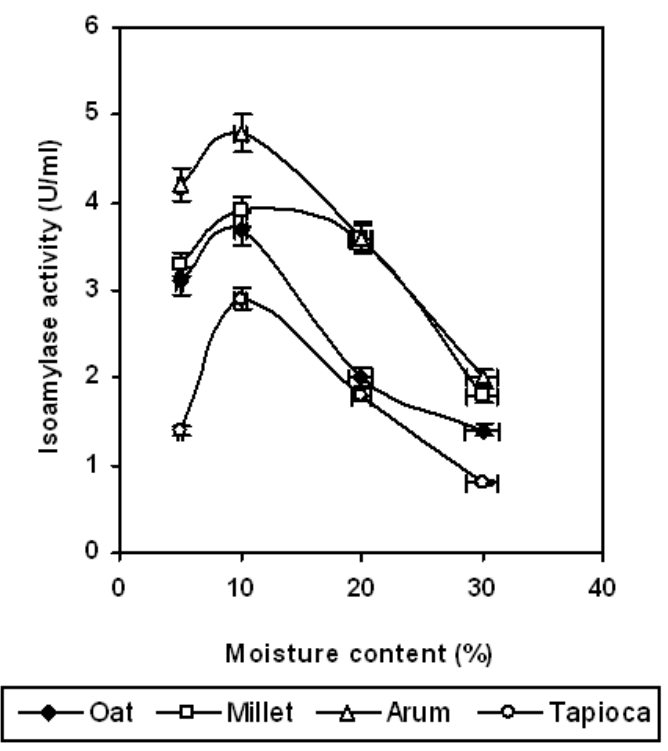

Figure 6 - Effect of moisture content on the production of isoamylase by R.oryzae.

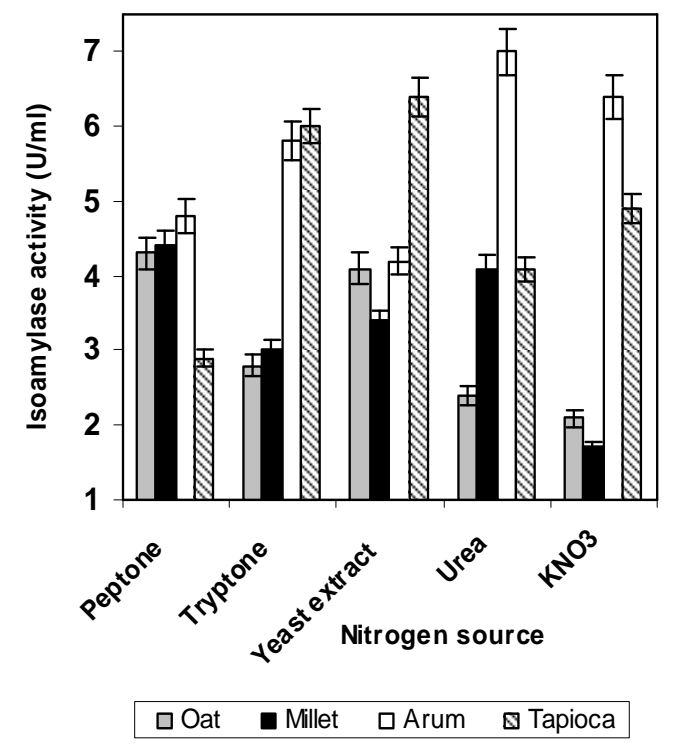

Figure 7 - Effect of nitrogen source on the production of isoamylase by R.oryzae. 


\section{Effect of metal ions}

The effect of various metal ions on the four starchy wastes for isoamylase production by $R$. oryzae PR7 in SSF was investigated by supplementing the medium with $10 \mathrm{mM}$ of the respective cations. Results showed that different metal ions had different effect on the four substrates. $\mathrm{K}^{+}$enhanced the enzyme activity in the case of millet and tapioca; $\mathrm{Ca}^{2+}$ and $\mathrm{Mn}^{2+}$ in the case of oat and arum; while $\mathrm{Mg}^{2+}$ enhanced ir for arum only (Fig 8). Loss of enzyme activity in the presence of $\mathrm{Cu}^{2+}$ was probably due to the inactivation of thiol groups present at the active site of the enzyme produced.

\section{Effect of additives}

To study the effect of various additives on the four substrates for isoamylase production, the medium was supplemented with $1 \mathrm{mM}$ of GSH, DTT, pCMB, histidine and cysteine. Results showed that cysteine had the best effect on isoamylase production in millet, arum and tapioca; GSH gave the best result in arum; while DTT and histidine gave the best result only in case of millet (Fig 9).The complete and partial reduction of enzyme activity in the presence of $\mathrm{pCMB}$, a potent thiol inhibitor and increase in the presence of externally added thiols like DTT, GSH and cysteine confirmed the presence of thiol group at the active site of the enzyme.

\section{Effect of surfactants}

All the four waste substrates showed different response towards different surfactants (Fig10). Triton X-100 induced enzyme activity in all the four substrates. Tween-20 gave best result only in case of millet; while Tween-40 and Tween-80 enhanced enzyme activity in oat, millet and tapioca. On the other hand, SDS reduced the enzyme production on all the four substrates used.

\section{Effect of Cultivation Time}

Highest isoamylase production was achieved in 72 $h$ of cultivation in case of SSF of the four agro wastes used. This rapid rate of growth conferred with the similar growth rate of 70-72 $\mathrm{h}$ taken by other isoamylase producer such as Bacillus sp (Ara et al., 1993), Flavobacterium sp, Micrococcus sp and Arthrobacter sp (Yamada et al., 1994). Enzyme production did not further increase after $72 \mathrm{~h}$ of growth in SSF (Fig. 11), probably due to exhaustion of nutrient.

\section{Effect of substrate combination}

SSF of two mixed substrates $(0.25 \%$ each) was tested which showed that except tapioca, the inducing power of all the substrates was increased when applied with other substrate. Although oat and arum individually at a concentration of $0.25 \%$ showed isoamylase activity of 4.3 and $2.9 \mathrm{U} / \mathrm{ml}$, respectively (Fig 2), the combination of these two resulted in the production of $7.1 \mathrm{U} / \mathrm{ml}$ (Fig 12). This level of production could not be achieved from the SSF of $0.5 \%$ oat or arum, or even from the combined SSF of $0.5 \%$ oat and $0.5 \%$ arum (data not shown).

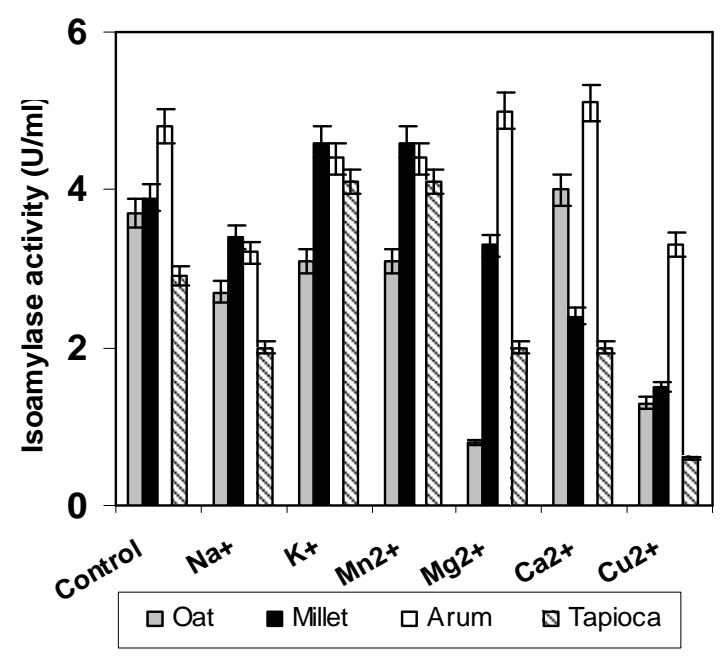

Figure 8 - Effect of metal ions on the production of isoamylase by R.oryzae. 


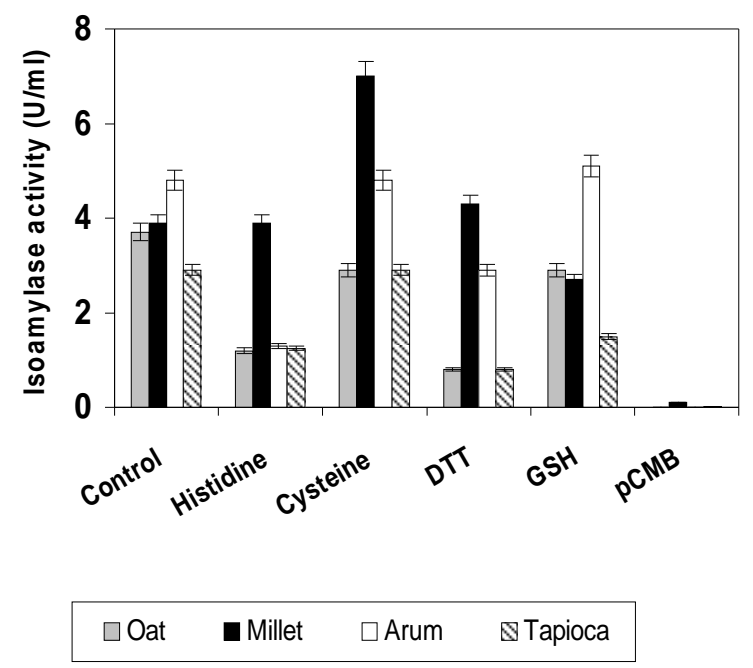

Figure 9 - Effect of additives on the production of isoamylase by R.oryzae.

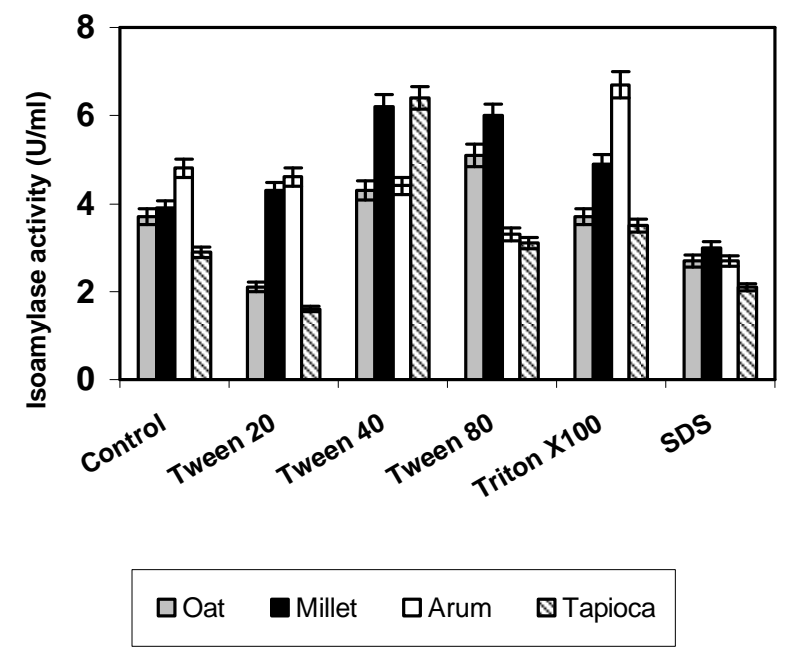

Figure 10 - Effect of surfactants on the production of isoamylase by R.oryzae.

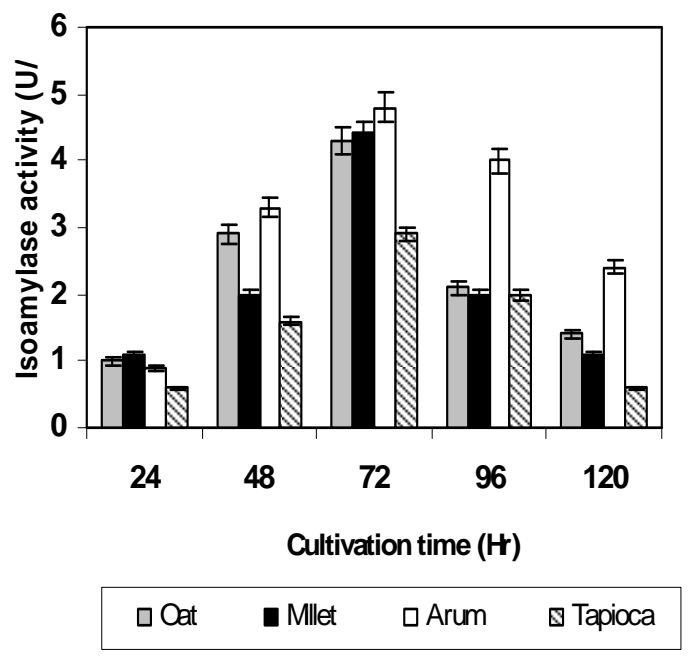

Figure 11 - Effect of cultivation time on the production of isoamylase by R.oryzae. 


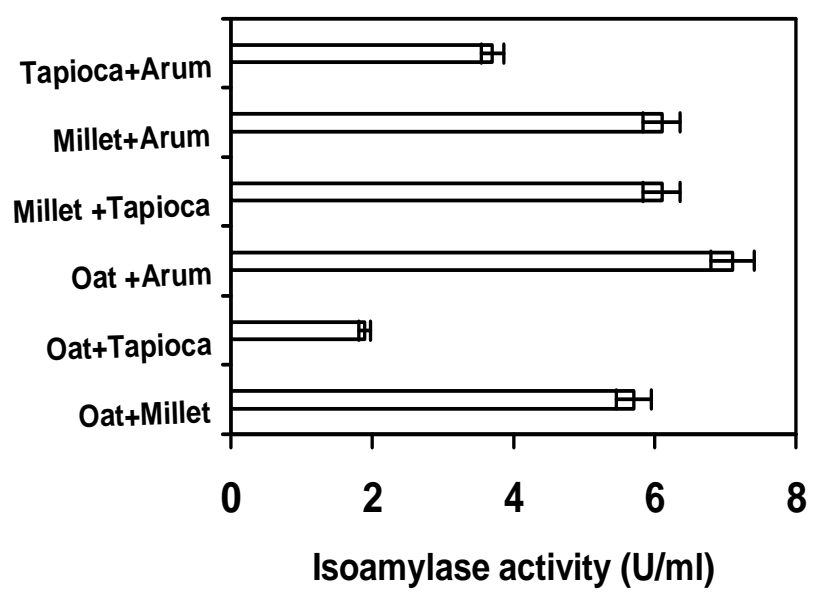

Figure 12 - Effect of combined substrates on the production of isoamylase by R.oryzae.

\section{CONCLUSION}

From the results it could be concluded that fungus strain of $R$ oryzae could be successfully used for the production of isoamylase in SSF. This is the first report on the production of isoamylase by Rhizopus oryzae showing the ability to synthesize high amount of extra-cellular isoamylase in SSF within a relatively short period of time, utilizing agro wastes such as oat, millet, arum and tapioca that would otherwise cause environmental pollution. Obviously, the properties of the present strain, found to be more advantageous from industrial point of view could be used for rapid and commercial production of isoamylase.

\section{ACKNOWLEDGEMENT}

The authors are thankful to University Grants Commission, New Delhi, India for the financial support.

\section{REFERENCES}

Acharya, P.B; Acharya, D.A; Modi, H.A. (2008), Optimization for cellulase production by Aspergillus niger using saw dust as substrate. African $J$. Biotech., 7, 4147-4152.

Akhila, R; Jayalakshmi Gopinatha, K; Tholath Emilia, A.(2010), Solid State production of manganese peroxidases using arecanut husk as substrate. Braz. Arch. Biol. Technol., 53, 555-562
Ara, K; Saeki, K; Ito, S. (1993), Purification and characterization of an alkaline isoamylase from an alkalophilic strain of Bacillus. J. General Microbiol., 139,781-786.

Arlem Nascimento de O; Luiz Antonio de O; Jerusa Souza, A, (2010),Partial characterization of amylases of two indigenous Central Amazonian rhizobia strains. Braz. Arch. Biol. Technol., 53, 35-45.

Castro, G. R; Garcia, G.F; Sineriz, F. (1992), Extracellular isoamylase produced by Bacillus circulans MR-137. J. App. Microbiol., 73, 520-523. 10.1111/j.1365-2672.1992.tb05015.x

Chimata, M.P; P. Sasidhar; C. Suresh (2010), Production of extracellular amylase from agricultural residues by a newly isolated Aspergillus species in solid state fermentation. African J. Biotech., 9, 51625169.

Ellaiah, V; Adinarayana, K; Bhavani, Y; Padmaja, P; Srinivasulu, B. (2002), Optimization of process parameters for glucoamylase production under solidstate fermentation by a new isolated Aspergillus species. Proc. Biochem., 38, 615- 620.

Fang, T.Y; Lin, L.L; Hsu, W.H. (1994), Recovery of isoamylase from Pseudomonas amyloderamosa by adsorption elution on raw starch. Enz. Microbial Technol., 16, 247-252.

Ghosh, B. and Ray, R.R. (2010), Saccharification of Raw Native Starches by Extracellular Isoamylase of Rhizopus oryzae. Biotechnol., 9, 224-228.

Gomes, I; Gomes, J; Steiner, W. (2003), Highly thermostable amylase and pullulanase of the extreme thermophilic eubacterium Rhodothermus marinus production and partial characterization. Biores. Technol., 90, 207-214.

Gunja, Z.H; Manners, D. J; Maung, K. (1961), Studies on carbohydrate-metabolizing enzymes. 7. Yeast isoamylase Biochemical J., 81, 392-398. 
Gunja-Smith, Z; Marshall, J.J; Mercier, C; Smith, E.E; Whelan, W.J. (1970), A glycogen debranching enzyme from Cytophage. FEBS Lett., 12, 96-100.

Harada, T; Misaki, A; Akai, H; Yokobayashi, K; Sugimoto, K. (1972), Characterization of Pseudomonas isoamylase by its actions on amylopectin and glycogen: comparison with Aerobacter pullulanase. Biochim. et Biophys. Acta (BBA) - Enzymol., 268, 497-505.

Kapnoor, S. and Mulilani, V.H. (2010), Production of $\alpha$-Galactosidase by Aspergillus oryzae through solidstate fermentation and its application in soy milk galactooligosaccharide hydrolysis. Braz. Arch. Biol. Technol., 53, 211-218.

Kar, S; Datta,T.K;Ray,R.C. (2010),Optimization of thermostable $\alpha$ - amylase production by Streptomyces erumpens MTCC 7317 in solid-state fermentation using cassava fibrous residue. Braz. Arch. Biol. Technol., 53, 301-309.

Karmakar, M. and Ray,R.R. (2010), Extracellular endoglucanase production by Rhizopus oryzae in liquid and solid state fermentation of Agro wastes. Asian J. Biotech., 2, 27-36.

Miller, G. L. (1959), Use of dinitrosalicylic acid reagent for determination of reducing sugar. Anal. Chem., 31(3): 426-428.

Morrrow, C.A. and Fraser, J.A. (2009), Sexual reproduction and dimorphism in the pathogenic basidiomycetes. FEMS Yeast Res., 9, 161-177.

Odibo, F. J. C; Okafor, N; Tom, M.U; Oyeka, C.A. (1992), Purification and some properties of a starch debranching enzyme of Hendersonula toruloidea. World J. Microbiol. Biotechnol., 8,102-105.

Olemposka-Beer, Z. (2007), Isoamylase from Pseudomonas amyloderamosa. Chem. Tech. Assess., 1- 6.

Omojasola, P.F. and Jilani, O.P. (2008), Cellulase production by Trichoderma longi, Aspergillus niger, Saccharomyces cerevisae cultured on Waste Materials from orange. Pakistan J. Biol. Sci., 11, 2382-2388.
Pandey, A (1992), Recent process developments in solid-state fermentation. Proc. Biochem., 27, 109117.

Pandey, A; Azmi, W; Singh, J; Banerjee, U. C., Types of fermentation and factors affecting it. In: Joshi VK, Pandey A, editors. Biotechnology: Food Fermentation., New Delhi: Educational Publishers, 1999, 383-426.

Ray, R. R. and Chakraverty, R. (1998), Extra cellular $\beta$ amylase from Syncephalastrum racemosum. Mycological Res., 102, 1563-1567.

Sakano,Y; Kobayashi, T; Kosugi, Y. (1969), Purification and substrate specificity of Yeast isoamylase. Agri. Biol. Chem., 33, 1535-1540.

Spancer Martins, I. (1982), Extracellular Isoamylase Produced by the Yeast Lipomyces kononenkoae. App. Envi. Microbiol.,44, 1253-1257.

Takahashi, K; Abe, J; Kojuma, T; Yoshida, M; Nakamura, N; Hizukuri, S. (1996), Production and application of an isosmylase from Flavobacterium odoratum. Enz. Microbial Technol.,19, 456- 461.

Tengerdy, R.P. Solid substrate fermentation for enzyme production. In: Pandey A, editor. Advances in Biotechnology. New Delhi: Educational Publishers \& Distributors, 1998, 13-6.

Ueda, S. and Nanri,N. (1967), Production of Isoamylase by Escherichia intermedia. App. Microbiol., 15, 492496.

Yamada, Y; Sato, T; Ohya, T. (1994), Isoamylase and process for producing the same. United States Patent $5352602,(1994.10 .04)$.

Zambare,V. (2010), Solid state fermentation of Aspergillus oryzae for glucoamylase production on agro residues. International J. Life Sci., 4,16-25. 